Ann C. T. M. Vossen', G. John M. Tibbe', Martin J. Kroos',

Jan G. J. van de Winkel ${ }^{3}$, Robbert Benner ${ }^{1}$ and

Huub F. J. Savelkoul ${ }^{1}$

${ }^{1}$ Department of Immunology, Erasmus University, Rotterdam, The Netherlands

${ }^{2}$ Department of Chemical Pathology, Erasmus University, Rotterdam, The Netherlands

${ }^{3}$ Department of Immunology, University Hospital, Utrecht, The Netherlands

\section{Fc receptor binding of anti-CD3 monoclonal antibodies is not essential for immunosuppression, but triggers cytokine-related side effects}

\begin{abstract}
A major drawback to the use of OKT3, a mouse anti-CD3 monoclonal antibody $(\mathrm{mAb})$, as an immunosuppressive agent is the associated cytokine release syndrome. We used a mouse model to elucidate the properties of anti-CD3 mAb responsible for these cytokine-related side effects. We have previously demonstrated that the hamster anti-CD3 mAb 145-2C11 induced strong cytokine release and morbidity in vivo, whereas two rat anti-CD3 $\mathrm{mAb} 17 \mathrm{~A} 2$ and $\mathrm{KT} 3 \mathrm{did}$ not. In the current study, we show that the mitogenic capacity of soluble anti$\mathrm{CD} 3 \mathrm{mAb}$ in vitro correlates with their induction of side effects in vivo. Mitogenesis in vitro and tumor necrosis factor- $\alpha$ (TNF- $\alpha$ ) release in vivo induced by anti-CD3 mAb could be inhibited by the anti-Fc $\gamma \mathrm{R}$ mAb 2.4G2, indicating that Fc $\gamma \mathrm{R}$ binding of anti-CD3 mAb is responsible for their mitogenic properties and for their induction of side effects. Importantly, the two non-mitogenic rat anti$\mathrm{CD} 3 \mathrm{mAb}$ were equally capable of suppressing skin allograft rejection as the mitogenic hamster anti-CD3 mAb, suggesting Fcy $\mathrm{R}$ binding of anti-CD3 $\mathrm{mAb}$ is not essential for their immunosuppressive properties. This suggestion is reinforced by our demonstration that administration of $2.4 \mathrm{G} 2$ in vivo did not interfere with immunosuppression of skin allograft rejection by 145-2C11. These findings suggest that clinical use of non-mitogenic anti-CD3 $\mathrm{mAb}$ will result in effective immunosuppression without cytokine-related side effects.
\end{abstract}

\section{Introduction}

The murine anti-CD3 mAb OKT3 is widely used for prevention and treatment of clinical organ allograft rejection because of its known immunosuppressive properties $[1,2]$. However, treatment with this mAb is accompanied by severe clinical symptoms, such as fever, chills, nausea, vomiting, headache, and diarrhea. These side effects have been related to an early systemic release of several cytokines, such as IL-2, TNF- $\alpha$, IFN- $\gamma$ and IL-6 [3, 4], probably produced by activated Tlymphocytes [5]. This so-called cytokine release syndrome precludes the use of anti-CD3 $\mathrm{mAb}$ in the treatment of autoimmune diseases.

We developed a mouse model to elucidate the properties of anti-CD3 $\mathrm{mAb}$ responsible for these undesirable side effects. The strength of this model is that it is based on three anti-CD3 mAb with similar immunosuppressive capacity in a mouse skin transplantation model [6]. Furthermore, all three $\mathrm{mAb}$ induced Tcell depletion and TcR/CD3 complex modulation [6]. One of these mAb, the hamster mAb 145$2 \mathrm{C11}$ [7], triggers strong cytokine release, accompanied by severe physical reactions consisting of piloerection, hypothermia, hypomotility and diarrhea $[8,9]$. Interestingly, this was not observed with the anti-CD3 mAb 17A2 (rat IgG2b) [10] and KT3 (rat IgG2a) [6, 11].

In the present study, the role of $\mathrm{Fc} \gamma \mathrm{R}$ was assessed by using an FcyR-blocking mAb, 2.4G2 [12] both in vitro and in

[I 14067]

Correspondence: Ann C. T. M. Vossen, Department of Immunology, Erasmus University Rotterdam, P.O. Box 1738, 3000 DR Rotterdam, The Netherlands (Fax: 31-10-4367601)

Key words: Anti-CD3 monoclonal antibodies / Immunosuppression / Side effects / CD3 vivo. Our results demonstrate that $\mathrm{Fc} \gamma \mathrm{R}$ binding in vivo is responsible for cytokine release and side effects following anti-CD3 mAb treatment. Most importantly, this study provides direct evidence that $\mathrm{Fc} \gamma \mathrm{R}$ binding of anti-CD3 $\mathrm{mAb}$ in vivo is not necessary for immunosuppression. Therefore, these data may have important clinical implications.

\section{Materials and methods}

\subsection{Monoclonal antibodies}

We used the anti-mouse CD3 mAb 17A2, rat IgG2b [10], $\mathrm{KT} 3$, rat IgG2a [11] and $145-2 \mathrm{C} 11$, a hamster $\mathrm{mAb}$ [7]. 2.4G2 [12], a rat IgG2b mAb directed against mouse Fc $\gamma$ RII/III [13], that also binds Fc $\gamma \mathrm{RI}$ via its Fc-portion [12], and $F\left(a^{\prime}\right)_{2}$ fragments of $2.4 \mathrm{G} 2$ (kindly provided by Dr. M. Daëron, Institut Curie, Paris, France [14]) were used to block Fc $\gamma \mathrm{R}$ binding of anti-CD3 mAb. As isotype control mAb, we used PH2-4a (rat IgG2b), PH2-104 (rat IgG2a), both directed against Escherichia coli $\beta$ galactosidase (kindly provided by Dr. J. van Denderen, Department of Immunology, Rotterdam, The Netherlands), and anti-TcR $\gamma \delta$ mAb GL3 (hamster Ig) [15]. We used P1.17, a mouse IgG2a Ab of unknown specificity [16], to compete for Fc $\gamma \mathrm{RI}$ binding.

mAb were purified from hybridoma culture supernatants by protein $G$ (Pierce, Oud-Beijerland, The Netherlands) affinity chromatography, as described [17].

\subsection{Mice}

For all experiments in vitro and as skin graft recipients, we used C57BL/Ka mice (H-2 $)$. B6.C-H-2 $2^{\mathrm{bm} 12}\left(\mathrm{H}-2^{\mathrm{bm} 12}\right)$ mice 
were used as skin graft donors. All mice were bred at the Department of Immunology of the Erasmus University, Rotterdam. Mice were kept in light-cycled rooms and had access to acidified water and pelleted food ad libitum.

\subsection{Proliferation assays}

Spleen cells $\left(2 \times 10^{5} /\right.$ well $)$ were cultured in $200 \mu \mathrm{l}$ RPMI 1640 medium (Gibco, Paisley, GB) supplemented with $10 \%$ heat-inactivated FCS, $4 \mathrm{mM} \mathrm{L}$-glutamine, $5 \times 10^{-5} \mathrm{M}$ $\beta$-mercaptoethanol, $100 \mathrm{IU} / \mathrm{ml}$ penicillin and $50 \mu \mathrm{g} / \mathrm{ml}$ streptomycin. Cells were incubated with different concentrations of anti-CD3 mAb in round-bottom tissue culture plates (Falcon). Alternatively, cells were cultured on anti-CD3 mAb coated flat-bottom tissue culture plates (Falcon). After $48 \mathrm{~h}$ of culture at $37^{\circ} \mathrm{C}$ in $5 \% \mathrm{CO}_{2}$ in air, $0.5 \mu \mathrm{Ci}\left[{ }^{3} \mathrm{H}\right]$ thymidine was added to each well, and $18 \mathrm{~h}$ later, cells were harvested and $\left[{ }^{3} \mathrm{H}\right]$ thymidine incorporation was measured in a liquid scintillation counter. The role of Fc $\gamma \mathrm{R}$ in anti-CD3 induced mitogenesis was examined by adding $10 \mu \mathrm{g} / \mathrm{ml} 2.4 \mathrm{G} 2 \mathrm{mAb}$ or an equivalent molar amount $(6.7 \mu \mathrm{g} / \mathrm{ml}) 2.4 \mathrm{G} 2 \mathrm{~F}\left(\mathrm{ab}^{\prime}\right)_{2}$ fragments to culture wells. In other wells, $10 \mu \mathrm{g} / \mathrm{ml}$ P1.17 (mouse IgG2a) [16] was added to compete for high-affinity Fc $\gamma$ RI binding. In control wells, cells were cultured with isotype-control $\mathrm{mAb}$ or Con A $(5 \mu \mathrm{g} / \mathrm{ml})$.

\subsection{Blocking of Fcy $\mathrm{R}$ in vivo}

The role of FcyR binding in TNF- $\alpha$ release and immunosuppression induced by 145-2C11 was examined by blockade of FcyR in vivo. C57BL/Ka mice were injected i.p. with $250 \mu \mathrm{g}$ of $2.4 \mathrm{G} 2 \mathrm{mAb} 12$ to $18 \mathrm{~h}$ before injection of

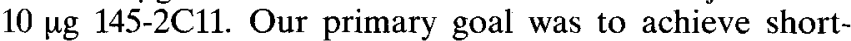
term blocking of $F c \gamma R$, since the effects of $10 \mu \mathrm{g}$ of 145 $2 \mathrm{C} 11$ can be detected early after injection $[6,18]$. This dose of $2.4 \mathrm{G} 2$ has previously been shown to inhibit $\mathrm{Fc} \gamma \mathrm{R}$ mediated sequestration of immune complexes for at least $24 \mathrm{~h} \mathrm{[19].}$

\subsection{Detection of serum TNF- $\alpha$}

For induction of TNF- $\alpha$ release, $10 \mu \mathrm{g}$ 145-2C11 mAb were injected i.v. The role of Fc $\gamma \mathrm{R}$ in TNF- $\alpha$ release was studied by $2.4 \mathrm{G} 2$ administration, 12 to $18 \mathrm{~h}$ before $145-2 \mathrm{C} 11 \mathrm{mAb}$ injection. Control mice were injected with $2.4 \mathrm{G} 2$ alone or $0.5 \mathrm{ml}$ BSS. At $1,2,4,8$, and $24 \mathrm{~h}$ after $145-2 \mathrm{C} 11 \mathrm{mAb}$ injection, 3 or 5 mice per group were killed using carbon dioxide asphyxiation. Blood was obtained via heart puncture in sterile tubes and left to clot overnight at $4{ }^{\circ} \mathrm{C}$. After centrifugation, serum samples were aliquotted and stored at $-70^{\circ} \mathrm{C}$.

Serum TNF- $\alpha$ levels were determined by a cytotoxicity assay on WEHI-164 clone 13 cells [20]. Briefly, trypsinized WEHI-164 cells were seeded in flat-bottom tissue culture plates (Falcon) at $1 \times 10^{4}$ cells $/ 100 \mu \mathrm{l}$ complete medium. After overnight cell adherence at $37^{\circ} \mathrm{C}$, serum samples and actinomycin D $(1 \mu \mathrm{g} / \mathrm{ml})$ were added and incubated for $24 \mathrm{~h}$ at $37^{\circ} \mathrm{C}$. Cytotoxic activity was measured with the MTT assay [21].

\subsection{Skin grafting}

The immunosuppressive effect of 145-2C11 mAb on MHC class II-disparate skin allograft rejection was studied by administration of $10 \mu \mathrm{g} \mathrm{mAb}$ the day before grafting. Fc $\gamma$ R-blockade was achieved by $2.4 \mathrm{G} 2 \mathrm{mAb}$ injection 12 to $18 \mathrm{~h}$ before $145-2 \mathrm{C} 11$ treatment. Control mice received $2.4 \mathrm{G} 2 \mathrm{mAb}$ alone or $0.5 \mathrm{ml} \mathrm{BSS}$.

Tail skin of B6.C-H-2 $2^{\text {bm12 }}$ donors was grafted to the dorsal thorax of C57BL/Ka recipients using a modification of the method of Billingham and Medawar [22]. Grafts were considered rejected when no viable donor skin was detectable.

\subsection{Statistical analyses}

The induction of T cell proliferation and TNF- $\alpha$ release by anti-CD3 mAb was compared by analysis of variance (ANOVA). If ANOVA revealed significant differences, the groups were compared using Student's $t$-test. Graft survival of groups was compared by Mann Whitney tests. Values of $p<0.05$ were considered significant.

\section{Results}

\section{1 $\mathrm{T}$ lymphocyte proliferation induced by immobilized and soluble anti-CD3 mAb}

To induce Tcell proliferation, anti-CD3 $\mathrm{mAb}$ had to be cross-linked either by Fc $\gamma \mathrm{R}^{+}$cells or by solid phase immobilized $\mathrm{mAb}$. The use of immobilized anti-CD3 $\mathrm{mAb}$ enabled the study of their mitogenic properties independent of their Fc $\gamma \mathrm{R}$ binding capacity [23]. Figure $1 \mathrm{~A}$ shows that immobilized anti-CD3 mAb, rat IgG2a and hamster $\mathrm{mAb}$ induced comparable $\mathrm{T}$ cell proliferation. The proliferation curve of rat IgG2b anti-CD3 $\mathrm{mAb}$ was significantly different from that of the two other anti-CD3 mAb. At higher concentrations, $17 \mathrm{~A} 2$ (rat $\mathrm{IgG} 2 \mathrm{~b}$ ) was significantly

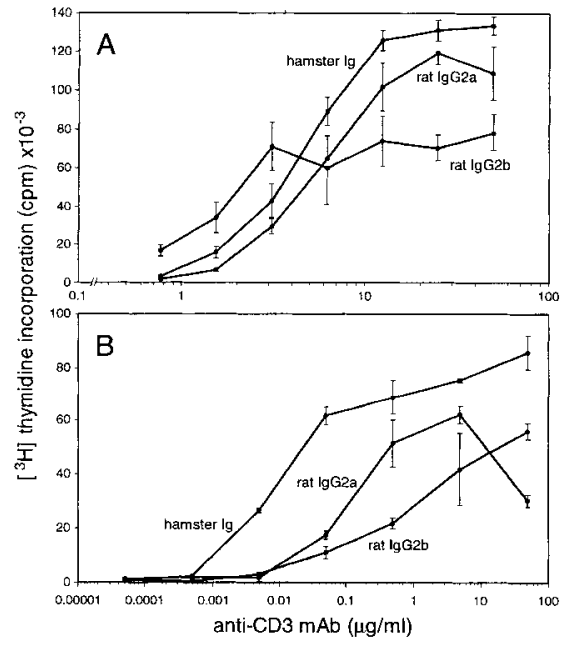

Figure 1. Proliferation induced by anti-CD3 mAb. C57BL/Ka spleen cells were stimulated with different concentrations of immobilized (A) or soluble (B) rat IgG2b, rat IgG2a or hamster anti-CD3 $\mathrm{mAb}$. The data represent mean $\mathrm{cpm}$ of triplicate cultures \pm SD. Experiments were repeated three times, yielding essentially identical results. 


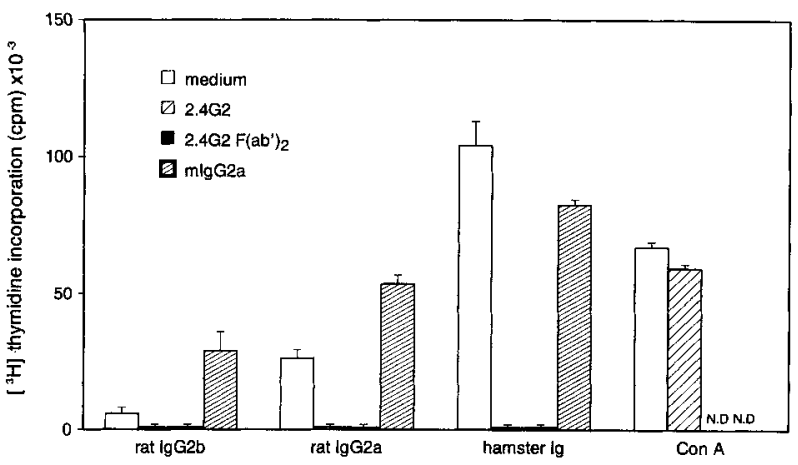

Figure 2. Effect of FcyR-blocking on proliferation induced by soluble anti-CD3 mAb or Con A. C57BL/Ka spleen cells were cultured in medium alone or medium supplemented with $2.4 \mathrm{G} 2$ $\mathrm{mAb}, \mathrm{F}\left(\mathrm{ab}^{\prime}\right)_{2}$ fragments of $2.4 \mathrm{G} 2$ or mIgG2a. T cell mitogenesis was induced by addition of $10 \mu \mathrm{g} / \mathrm{ml}$ rat $\operatorname{IgG} 2 \mathrm{~b}$, rat $\operatorname{IgG} 2 \mathrm{a}$ or hamster anti-CD3 mAb. Data represent mean cpm of triplicate cultures \pm SD. N.D. $=$ not determined. Similar results were obtained in a second experiment (not shown).

less mitogenic than the other mAb, whereas at lower concentrations this $\mathrm{mAb}$ was significantly more mitogenic.

The capacity of soluble anti-CD3 mAb to induce T cell proliferation has been shown to correlate with the extent of their interaction with Fc $\gamma \mathrm{R}$ [24]. Soluble rat IgG2b and rat IgG2a anti-CD3 mAb induced comparable T cell proliferations (Fig. 1B). To induce T cell proliferation, high concentrations (consistently 50-100 times higher than 145$2 \mathrm{C} 11 \mathrm{mAb}$ ) of rat anti-CD3 mAb were needed. Neither of the isotype control mAb (PH2-4a, PH2-104 and GL3) induced proliferation (data not shown).

Addition of FcyR-blocking mAb (10 $\mu \mathrm{g} / \mathrm{ml} \mathrm{2.4G2)} \mathrm{com-}$ pletely inhibited proliferation induced by all three soluble anti-CD3 $\mathrm{mAb}$ (Fig. 2). This inhibition was specific, since addition of $10 \mu \mathrm{g} / \mathrm{ml}$ of an isotype-control mAb (PH2-4a) had no effect on anti-CD3 mAb-induced proliferation (data not shown), and Con A induced proliferation was not affected by $2.4 \mathrm{G} 2 \mathrm{mAb}$ (Fig. 2). Highly purified $\mathrm{F}\left(\mathrm{ab}^{\prime}\right)_{2}$ fragments of $2.4 \mathrm{G} 2$ that only block FcyRII/III binding had a similar inhibitory effect to that of intact 2.4G2 (Fig. 2). In addition, competition for Fc $\gamma$ RI binding

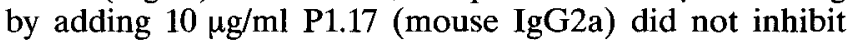
anti-CD3 mAb-induced T cell proliferation (Fig. 2). Thus, mitogenesis caused by all three anti-CD3 mAb involved Fc $\gamma$ RII/III molecules. The ability of low doses of hamster $\mathrm{mAb}$ to induce significant $\mathrm{T}$ cell proliferation suggests that this $\mathrm{mAb}$ has a high affinity for either FcyRII or FcyRIII.

\subsection{Effect of FcyR-blocking mAb on TNF- $\alpha$ release triggered by $145-2 \mathrm{C11}$ in vivo}

Of the three anti-CD3 mAb, only $145-2 \mathrm{C} 11 \mathrm{mAb}$ induced cytokine-related side effects [6]. TNF- $\alpha$ has been shown to play a crucial role in these side effects [6,9]. Administration of $10 \mu \mathrm{g}$ hamster anti-CD3 mAb 145-2C11 in vivo induced a strong increase in serum TNF- $\alpha$ levels (Fig. 3). The highest TNF- $\alpha$ serum levels were measured $1 \mathrm{~h}$ after 145-2C11 injection. To determine the role of FcyR in this TNF- $\alpha$ release, we temporarily blocked FcyR by giving $250 \mu \mathrm{g} 2.4 \mathrm{G} 2 \mathrm{mAb} 12$ to $18 \mathrm{~h}$ before $145-2 \mathrm{C} 11$ injection.

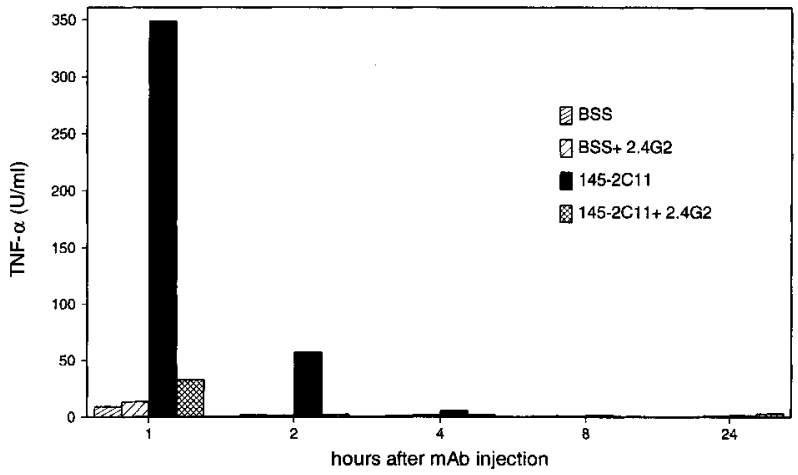

Figure 3. Effect of anti-Fc $\gamma \mathrm{R} \mathrm{mAb}$ in vivo on TNF- $\alpha$ release triggered by $145-2 \mathrm{C} 11 \mathrm{mAb}$. C57BL/Ka mice received either $10 \mu \mathrm{g}$ $145-2 \mathrm{C} 11 \mathrm{mAb}$ i.v. $(\mathrm{t}=0 \mathrm{~h}), 250 \mu \mathrm{g} 2.4 \mathrm{G} 2 \mathrm{mAb}(\mathrm{t}=-12$ to $-18 \mathrm{~h})$ or a combination of $145-2 \mathrm{C} 11$ and $2.4 \mathrm{G} 2 \mathrm{mAb}$. Control mice received $0.5 \mathrm{ml}$ BSS. At $1,2,4,8$ and $24 \mathrm{~h}$ after treatment, 3 (2.4G2 and BSS group) or 5 (other groups) mice per group were killed for detection of serum TNF- $\alpha$. This experiment was performed twice. Results represent the mean serum TNF- $\alpha$ levels $(\mathrm{SEM} \leq 15 \%)$ from one representative experiment.

Treatment with $2.4 \mathrm{G} 2 \mathrm{mAb}$ completely abrogated the rise of serum TNF- $\alpha$ levels. Anti-Fc $\gamma \mathrm{R} m \mathrm{mAb}$ itself did not trigger TNF- $\alpha$ release. These results show that binding of 145$2 \mathrm{C} 11 \mathrm{mAb}$ to FcyR bearing cells is necessary for TNF- $\alpha$ release in vivo.

\subsection{Effect of Fc $\gamma \mathrm{R}$ blocking in vivo on 145-2C11-induced immunosuppression of skin allograft rejection}

Since $F c \gamma R$ blockade significantly inhibited the cytokine release syndrome caused by $145-2 \mathrm{C} 11 \mathrm{mAb}$, it was essential to determine whether this treatment interferes with the immunosuppressive effect of this anti-CD3 $\mathrm{mAb}$. Therefore, we studied the effect of the different treatment schedules on skin allograft rejection. The day after 145 $2 \mathrm{C} 11$ injection, C57BL/Ka mice received an MHC class IIdisparate B6.C-H-2 ${ }^{\text {bm12 }}$ skin graft. As shown in Fig. 4, a single dose of $10 \mu \mathrm{g} 145-2 \mathrm{C} 11$ significantly prolonged skin allograft survival compared to the untreated control group. The administration of $250 \mu \mathrm{g} 2.4 \mathrm{G} 2 \mathrm{mAb}$ had no

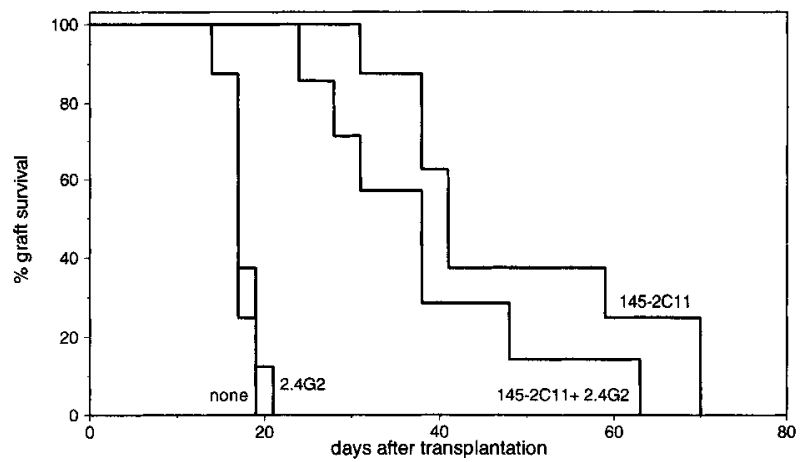

Figure 4. Effect of FcyR-blockade in vivo on 145-2C11-induced immunosuppression of skin allograft rejection. C57BL/Ka mice received an MHC class II-disparate B6.C-H-2 ${ }^{\mathrm{bm} 12}$ skin graft. On the day before grafting, the mice were treated with $10 \mu \mathrm{g} 145-2 \mathrm{C} 11$ $(n=8)$. One group received $250 \mu \mathrm{g} 2.4 \mathrm{G} 212$ to $18 \mathrm{~h}$ before 145 $2 \mathrm{C} 11$ administration $(n=7)$ and another received $2.4 \mathrm{G} 2 \mathrm{mAb}$ alone $(n=8)$. Control mice $(n=8)$ received no treatment. 
effect on the immunosuppression induced by $145-2 \mathrm{C} 11$. Furthermore, the group that received $2.4 \mathrm{G} 2 \mathrm{mAb}$ alone showed the same graft survival as the untreated control group. These results show that FcyR-mediated binding of anti-CD3 $\mathrm{mAb}$ is not essential for immunosuppression.

\section{Discussion}

Treatment and prevention of organ allograft rejection using OKT3 is very successful $[1,2]$. However, this treatment is complicated by the OKT3-induced cytokine release syndrome. In this study, we used a mouse model with three anti-CD3 $\mathrm{mAb}$ to characterize the properties of anti-CD3 $\mathrm{mAb}$ that are responsible for induction of cytokine-related side effects. Since all three $\mathrm{mAb}$ have been shown to be equally immunosuppressive [6], this model allows the study of $T$ cell activating capacities of anti-CD3 $\mathrm{mAb}$ independent of their immunosuppressive properties.

Differences in T cell activation by anti-CD3 mAb might be caused by differences in epitope recognition or affinity of the $\mathrm{mAb}[24,25]$. Earlier studies $[10,11]$ showed crosscompetition between 17A2, KT3 and 145-2C11 mAb, suggesting that the three anti-CD3 $\mathrm{mAb}$ recognize similar or closely related epitopes. The hamster mAb 145-2C11 has been shown to be specific for the CD3 epsilon chain [7]. Furthermore, the anti-CD3 $\mathrm{mAb}$ bound with similar affinity $\left(K_{d}\right.$ of $\left.2.5 \times 10^{-9}-3 \times 10^{-9} \mathrm{M}\right)$ to lymph node cells (data not shown).

Mitogenesis and $\mathrm{T}$ cell activation in vitro caused by anti$\mathrm{CD} 3 \mathrm{mAb}$ is dependent on interaction of these $\mathrm{mAb}$ with FcyR [26]. The finding that $145-2 \mathrm{C} 11 \mathrm{~F}\left(\mathrm{ab}^{\prime}\right)_{2}$ fragments induce less cytokine release and morbidity in mice than intact $145-2 \mathrm{C} 11 \mathrm{mAb}$ suggests that Fcy $\mathrm{R}$ binding is also involved in Tcell activation in vivo $[9,27]$, though interpretations may be influenced by the short half-life of $\left.\mathrm{F}(\mathrm{ab})_{2}\right)_{2}$ fragments. Our results demonstrate in a mouse model that intact non-mitogenic anti-CD3 $\mathrm{mAb}$ induced less cytokine-related side effects than mitogenic mAb [6]. This difference in mitogenesis is due to differences in FcR binding capacities of the anti-CD3 $\mathrm{mAb}$, since in immobilized form, all three $\mathrm{mAb}$ induced $\mathrm{T}$ cell proliferation. The mitogenic anti-CD3 mAb 145-2C11 displayed a higher affinity for Fc $\gamma$ RII or Fc $\gamma$ RIII than the non-mitogenic $\mathrm{mAb} 17 \mathrm{~A} 2$ and KT3. The first direct evidence for the role of Fcr $\mathrm{R}$ binding in the cytokine-related side effects of antiCD3 $\mathrm{mAb}$ is provided by our finding that blocking of Fc $\gamma \mathrm{R}$ binding in vivo resulted in complete inhibition of TNF- $\alpha$ release by $145-2 \mathrm{C} 11 \mathrm{mAb}$.

Our previous study showed that the non-mitogenic rat anti-CD3 mAb $17 \mathrm{~A} 2$ and KT3 are equally effective as the mitogenic 145-2C11 mAb in suppressing skin allograft rejection [6]. That $\mathrm{Fc} \gamma \mathrm{R}$ binding of anti-CD3 $\mathrm{mAb}$ is not essential for their immunosuppressive properties is further shown by our finding that blocking of $F \mathrm{c} \gamma \mathrm{R}$ binding in vivo has no effect on the suppression of skin allograft rejection by $145-2 \mathrm{C} 11 \mathrm{mAb}$.

Together, our data suggest that the use of non-mitogenic anti-CD3 mAb would cause the induction of fewer cytokine-related side effects, while retaining effective immunosuppression. Though $F\left(a b^{\prime}\right)_{2}$ fragments have been proposed to be useful in the clinical situation, a major drawback of these fragments is their extremely short halflife and thus the necessity of frequent administration. In addition, the production of these fragments requires great care, since even minimal contamination with intact $\mathrm{mAb}$ may induce significant $T$ cell activation [26]. The use of whole non-mitogenic anti-CD3 mAb would therefore be much more preferable. An IgA switch variant of a murine anti-CD3 mAb, unable to interact with human FcyR, induces significantly less cytokine release and side effects in chimpanzees [28]. To date, the number of patients treated with these $\mathrm{mAb}$ are insufficient to allow conclusions on their immunosuppressive efficacy [29]. Alegre et al. [30] showed that mutations in the Fc portion of a humanized OKT3 resulted in reduced FcyR binding. In vitro, this mutated $\mathrm{mAb}$ also induced significantly less $\mathrm{T}$ cell activation than the parental $\mathrm{mAb}$, but displayed the same immunosuppressive properties. Recently, this mutated $\mathrm{mAb}$ has been shown to be equally effective in suppressing human skin graft rejection as the parental anti-CD3 $\mathrm{mAb}$ and OKT3 in SCID mice reconstituted with human splenocytes [31].

In summary, interaction of the hamster anti-CD3 $\mathrm{mAb}$ 145-2C11 with FcyRII/III is responsible for its cytokinerelated side effects. From a comparison of this $\mathrm{mAb}$ with two other anti-CD3 $\mathrm{mAb}$ that do not induce any morbidity, we conclude that mitogenesis in vitro correlates with cytokine release and morbidity in vivo. This finding is relevant for the development of new anti-CD3 mAb. Furthermore, Fc $\mathrm{R}$ binding is not essential for immunosuppression by anti-CD3 $\mathrm{mAb}$. Together these data suggest that non-mitogenic anti-CD3 $\mathrm{mAb}$ are promising immunosuppressive agents in clinical tissue and organ transplantation and that they may also be useful for treatment of autoimmune diseases.

We thank Dr. W. van Ewijk for critical review of the manuscript. This study was supported by the Dutch Kidney Foundation (Grant C91.1143).

Received February 13, 1995; in revised form March 31, 1995; accepted April 5, 1995.

\section{References}

1 Ortho Multicenter Transplant Study Group, N. Engl. J. Med. 1985. 313: 337

2 Norman, D. J., Kahana, L., Stuart, F. P. J., Thistlethwaite, J. R. J., Shield, C. F., Monaco, A., Dehlinger, J., Wu, S. C., Van Horn, A. and Haverty, T. P., Transplantation 1993. 55: 44.

3 Chatenoud, L., Ferran, C., Reuter, A., Legendre, C., Gevaert, Y., Kreis, H., Franchimont, P. and Bach, J. F., N. Engl. J. Med. 1989. 320: 1420.

4 Bloemena, E., ten Berge, I. J., Surachno, J. and Wilmink, J. M., Transplantation 1990. 50: 330.

5 Ferran, C., Dautry, F., Merite, S., Sheehan, K., Schreiber, R., Grau, G., Bach, J. F. and Chatenoud, L., J. Clin. Invest. 1994. 93: 2189.

6 Vossen, A. C., Knulst, A. C., Tibbe, G. J., van Oudenaren, A., Baert, M. R., Benner, R. and Savelkoul, H. F., Transplantation 1994. 58: 257.

7 Leo, O., Foo, M., Sachs, D. H., Samelson, L. E. and Bluestone, J. A., Proc. Natl. Acad. Sci. USA 1987. 84: 1374. 
8 Ferran, C., Sheehan, K., Dy, M., Schreiber, R., Merite, S., Landais, P., Noel, L. H., Grau, G., Bluestone, J., Bach, J. F. and Chatenoud, L., Eur. J. Immunol. 1990. 20: 509.

9 Alegre, M., Vandenabeele, P., Flamand, V., Moser, M., Leo, O., Abramowicz, D., Urbain, J., Fiers, W. and Goldman, M., Eur. J. Immunol. 1990. 20:707.

10 Miescher, G. C., Schreyer, M. and MacDonald, H. R., Immunol. Lett. 1989. 23: 113.

11 Tomonari, K., Immunogenetics 1988. 28: 455.

12 Unkeless, J. C., J. Exp. Med. 1979. 150: 580.

13 Ravetch, J. V. and Kinet, J. P., Annu. Rev. Immunol. 1991. 9: 457.

14 Daëron, M., Malbec, O., Bonnerot, C., Latour, S., Segal, D. M. and Fridman, W. H., J. Immunol. 1994. 152: 783.

15 Goodman, T. and Lefrancois, L., J. Exp. Med. 1989. 170: 1569.

16 Horibata, K. and Harris, A. W., Exp. Cell. Res. 1970. 60: 61.

17 Savelkoul, H. F., Vossen, A. C., Breedland, E. G. and Tibbe, G. J., J. Immunol. Methods 1994. 172: 33.

18 Ferran, C., Dy, M., Merite, S., Sheehan, K., Schreiber, R., Leboulenger, F., Landais, P., Bluestone, J., Bach, J. F. and Chatenoud, L., Transplantation 1990. 50: 642.

19 Kurlander, R. J., Ellison, D. M. and Hall, J., J. Immunol. 1984. 133: 855 .

20 Meager, A., Leung, H. and Woolley, J., J. Immunol. Methods 1989. 116: 1 .

21 Mosmann, T., J. Immunol. Methods 1983. 65: 55.

22 Billingham, R. E. and Medawar, P. B., J. Exp. Biol. 1951. 28: 385 .
23 Van Lier, R. A., Brouwer, M., Rebel, V. I., van Noesel, C. J. and Aarden, L. A., Immunology 1989. 68: 45.

24 Woodle, E. S., Thistlethwaite, J. R., Jolliffe, L. K., Ghobrial, I., Fuccello, A. J., Stuart, F. P. and Bluestone, J. A., Transplant. Proc. 1991. 23: 81.

25 Van Lier, R. A., Boot, J. H., Verhoeven, A. J., De Groot, E. R., Brouwer, M. and Aarden, L. A., J. Immunol. 1987. 139: 2873.

26 Woodle, E. S., Thistlethwaite, J. R., Ghobrial, I. A., Jolliffe, L. K., Stuart, F. P. and Bluestone, J. A., Transplantation 1991. 52: 354 .

27 Hirsch, R., Gress, R. E., Pluznik, D. H., Eckhaus, M. and Bluestone, J. A., J. Immunol. 1989. 142: 737.

28 Parlevliet, K. J., Jonker, M., Ten Berge, R. J., van Lier, R. A., Wilmink, J. M., Strengers, P. F., Aarden, L. A. and Schellekens, P. T., Transplantation 1990. 50: 889.

29 Parlevliet, K. J., Ten Berge, I. J., Yong, S. L., Surachno, J., Wilmink, J. M. and Schellekens, P. T., J. Clin. Invest. 1994. 93. 2519.

30 Alegre, M. L., Collins, A. M., Pulito, V. L., Brosius, R. A., Olson, W. C., Zivin, R. A., Knowles, R., Thistlethwaite, J. R., Jolliffe, L. K. and Bluestone, J. A., J. Immunol. 1992. 148: 3461

31 Alegre, M. L., Peterson, L. J., Xu, D., Sattar, H. A., Jeyarajah, D. R., Kowalkowski, K., Thistlethwaite, J. R., Zivin, R. A., Jolliffe, L. and Bluestone, J. A., Transplantation 1994. 57 : 1537. 